\title{
污濁防止膜カーテン強度の経時劣化評価法 に関する研究
}

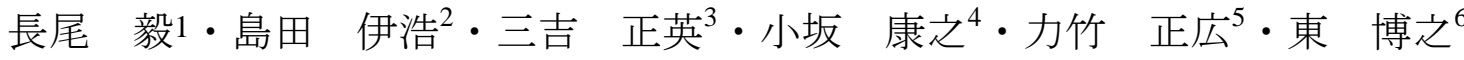 \\ 1正会員 神戸大学 都市安全研究センター（†657-8501 神戸市灘区六甲台町1-1） \\ E-mail:nagao@people.kobe-u.ac.jp \\ 2正会員（一財） 港湾空港総合技術センター（†100-0013 千代田区霞ヶ関3-3-1 尚友会館3階） \\ E-mail:shimada@scopenet.or.jp \\ 3 (一社) ウォーターフロント協会（干154-0001＼cjkstart東京都世田谷区池尻2-33-16） \\ E-mail:mm002463@mb.taiyokogyo.co.jp \\ 4 (一社) ウォーターフロント協会（テ154-0001 東京都世田谷区池尻2-33-16） \\ E-mail:DZE05162@nifty.ne.jp \\ 5 (一社) ウォーターフロント協会（干154-0001 東京都世田谷区池尻2-33-16） \\ E-mail:m.rikitake@hakusho.co.jp \\ 6 (一社) ウォーターフロント協会（干154-0001＼cjkstart東京都世田谷区池尻2-33-16) \\ E-mail:azuma@k-akebono.co.jp
}

海洋を主とする公有水面での浚渫工事や埋立工事等において，発生する污濁の拡散を防止するために設 置される污濁防止膜は，フロート部，カーテン部，アンカー等により構成され，近年カーテン部の再利用 が進んでいる. ポリエステル織物が一般に用いられるカーテン部は経時劣化が避けられないことから, 設 置期間に対応した劣化強度を見込んで設計が行われる。この劣化強度は, データ数が比較的乏しいことな ぞから，特に再利用品については従来かなり安全側の設定が行われてきた。本研究では，污濁防止膜カー テン強度の経時劣化評価法を構築することを目的として，実海域における実験データをはじめとする数多 くの経時劣化データを収集し, 設計に用いる劣化強度関数を提案した.

Key Words : silt curtain, tensile strength, strength deterioration, reuse

\section{1. はじめに}

污濁方止膜は，海洋を主とする公有水面での浚渫工事 や埋立工事等において，発生する污濁の拡散を防止する ために設置される構造物であり，資源の有効利用や廃棄 物の減量に資する観点から，近年再利用が進んでいる. 污濁方止膜の基本構成は，污濁拡散防止機能を有する力 ーテン部，カーテン部を垂直方向に安定させる機能を有 するフロート部，張力を受け持つテンション部及び污濁 防止膜を固定するための係留部等により構成される.

これらの部位のうち，フロート部，テンション部等の 経時劣化程度は比較的低いが，ポリエステル織物が一般 に用いられるカーテン部は経時劣化の影響が非常に大き い. このため, カーテン部の性能照査においては, 不確 定要因によるばらつき, 製品縫合の影響に加えて, 経時 による影響を考慮した部分係数を用いて強度の評価が行 われる1 . 経時劣化の影響を見込む部分係数は，初期利
用と再利用で異なる值が設定されており, データ数が比 較的乏しいことなどから，従来，特に再利用品について はかなり安全側の設定が行われてきた.
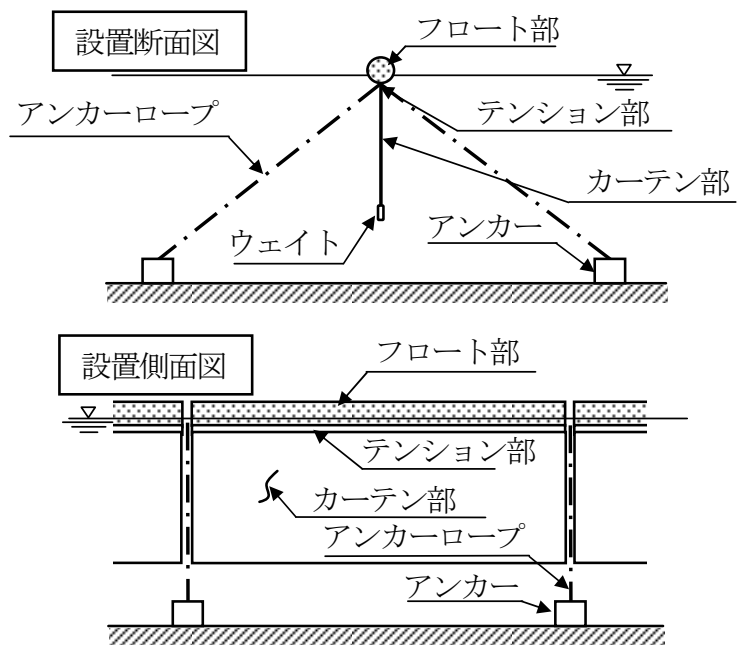

図-1 污濁防止膜構造例 
本研究では，污濁防止膜カーテン強度の経時劣化評価 法を構築することを目的として，実工事における製品回 収時の試験データや実海域における実験データ等の数多 くの経時劣化データを収集し，設計に用いる劣化強度関 数を提案した.

\section{2. カーテンの破断に関する現行の性能照査法 ${ }^{1)}$}

カーテンの破断に関する性能照査は，污濁防止膜 技術資料(案) $)^{1)}$ 従い行われることが一般的である. 以下では，本論での議論のために，現行の性能照査 法を簡単に紹介する。 カーテン部の性能照査は，カー テンに作用する張力がカーテン強度を超えないことを照 査することで行われる．標準的な性能照査式は式(1)の とおりである。

$$
T_{3} \geq \frac{3}{100} \gamma_{C} T_{C}
$$

ここに， $T_{3}$ : 3cm幅カーテン強度 $(\mathrm{N} / 3 \mathrm{~cm}), T_{C}$ : カー テンに作用する張力 $(\mathrm{N} / \mathrm{m}), \gamma_{C}$ : 部分係数である.

ここで，カーテンの強度試験はJIS L 1096のストリップ 法に準拠して3cm幅の試験体を対象に実施される。この ため，3cm幅の引張強度に相当する值がカーテン品番と して与えられ，\#300，\#500，\#800の3種類の品番のカー テンが我が国では生産されている。 それぞれの引張強度 の規格值は2942，4904，7846（N/3cm）である.

部分係数は式(2)により設定され，初期利用品につい ては表-1の值が用いられる。

$$
\gamma_{C}=k_{1} k_{2} k_{3}
$$

ここに， $k_{1}$ : 経時劣化による影響を表す係数， $k_{2}$ : 不 確定要因によるばらつきを表す係数， $k_{3}$ : 製品縫合によ る影響を表す係数である.

表-1 初期利用品に対寸る部分係数

\begin{tabular}{|c|c|c|c|}
\hline 予定設置期間 & 6ケ月まで & 6 ケ 12ケ月 & 12〜24ケ月 \\
\hline$k_{1}$ & 1.67 & 2.50 & 4.00 \\
\hline$k_{2}$ & 3.00 & 3.00 & 3.00 \\
\hline$k_{3}$ & 1.67 & 1.67 & 1.67 \\
\hline$\gamma_{C}$ & 8.00 & 12.00 & 20.00 \\
\hline
\end{tabular}

また，再利用品については，既設置期間と再利用予定 期間の合計が24ケ月までの範囲で，表-1の初期利用品に 対する部分係数のうち12〜24ケ月の值が用いられる. 既 設置期間と再利用予定期間の合計がたとえ12ヶ月より短

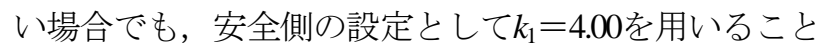
になる。これは，污濁防止膜技術資料（案）1)策定時に
おいて必ずしも十分な数のデータが得られていなかった ためであるといえる．図-2，図-3にそれぞれ污濁方止膜 技術資料(案) $)^{1}$ におけるカーテンの経時劣化データと設計 における設定の関係を示す。図-2, 図-3において, design valueとは経時劣化に関係して設計で用いる值であ り， $k_{1}$ の逆数として示している.

回帰式は，初期利用，再利用について，それぞれ式 (3)，式(4)に示すとおりである.

$$
\begin{aligned}
& r=\exp (-0.0436 m) \\
& r=\exp (-0.0437 m)
\end{aligned}
$$

ここに，r:強度低下率（試験值/規格值）， $m$ : 経過 月である.

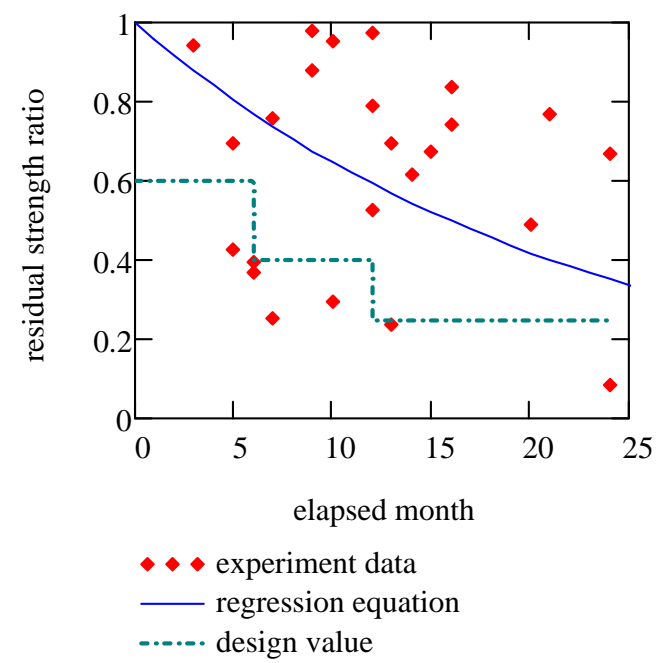

図-2 引張強度経時劣化（初期利用） ${ }^{1)}$

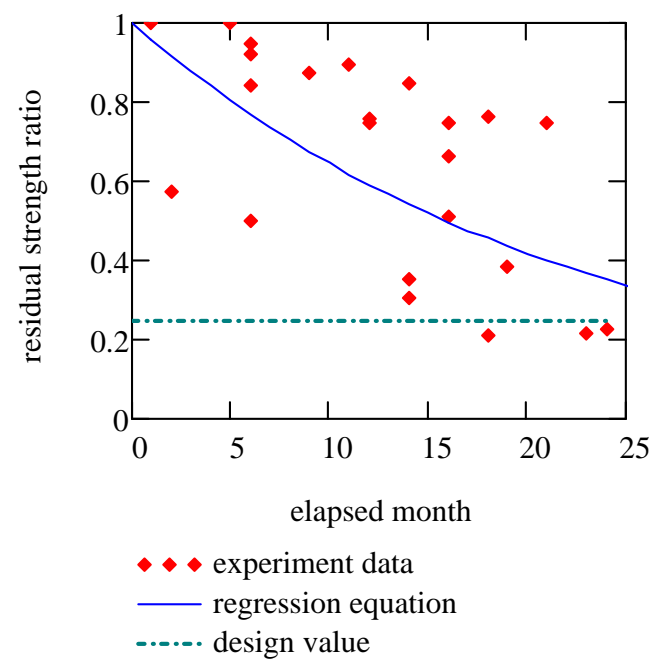

図-3 引張強度経時劣化（再利用） ${ }^{1)}$ 


\section{3. カーテン強度の経時劣化評価法の検討}

\section{(1) 収集データ}

検討に用いたデータは，(1)污濁防止膜技術資料(案) ${ }^{1}$ 策 定時に用いた2005年時点の收集データ，(2)新潟東港にお ける実海域実験データ²)，(3)近年の実工事におけるカー テン回収時の試験データの3種類のデータである. 品番 毎の収集データ数は表-2に示すとおりである. データ総 数は315であり，污濁防止膜技術資料(案) $)^{11}$ 策定時のデー 夕数48と比較すると，本研究では非常に多くのデー夕を 得たことになる.

表-2 収集データ数

\begin{tabular}{|l|c|c|c|}
\hline & $\# 300$ & $\# 500$ & $\# 800$ \\
\hline 2005年時点データ & 18 & 18 & 12 \\
\hline 新潟東港実海域実験データ & 21 & 10 & 10 \\
\hline 近年の実工事データ & 39 & 187 & 0 \\
\hline
\end{tabular}

以上のうち新潟東港における実海域実験データは，詳 細は文献2)に示されるとおりであるが，簡単に実験内容 を紹介しておく、当該実験は, 新潟東港の実験海域にカ 一テン部1スパン（長さ20m，カーテン丈長 $3 \mathrm{~m} ） ， フ コ$ 一ト部 $\phi 400 \mathrm{~mm}$, および係留索を平成23年8月下旬から 平成24年10月初旬まで設置し，原則1ヶ月毎に物理的特 性試験を行うことにより，同一海域でのカーテンの経年 劣化の状況を継続的に調査したものである．ただし，経 過5，6ヶ月は積雪のため欠測となっている. 実験体は\# 300, \#500, \#800の品番である.

この他のデータについては, 海域, 波浪等の作用, カ 一テン使用条件は様々であるが，条件の違いによる経年 劣化への影響を議論できるような詳細な条件データは残 されていない.

\section{（2）残留強度比の定義}

上述の通り我が国で生産される\#300, \#500, \#800の3 種類の品番のカーテンの引張強度の規格值はそれぞれ 2942，4904，7846（N/3cm）である。規格值とは実際の 製品がその值を下回らないことを保証する值であり，実 際の初期強度と規格值の比（初期強度比）はメーカーに よりばらつきがある。図-4には今回検討に用いた $315 テ ゙$ 一夕の初期強度比の頻度分布を示寸．初期強度比は1.06 から1.45の範囲にばらついており，平均值は1.19，標準 偏差は0.08である. 以降の検討に用いる残留強度比とし ては，実際には残留強度を初期值で除した值とすべきで あるが，設計実務上は規格值で除した值と定義する方が 取扱は簡単である.

しかしながら，このように初期強度比にばらつきが大 きい状態で残留強度比を規格值で除した值として設定し
た場合，実際のばらつき以上に残留強度のばらつきを評 価してしまうことになる.このため, 本研究では, 残留 強度比として, 残留強度に対する初期值の比として定義 した值を用いる。ここで, 初期值とは, 初期利用, 再利 用の違いにかかわらず，初期利用開始時の值としている. よって再利用についても，再利用開始時の值ではなく初 期の強度をもとにしていることに注意が必要である。

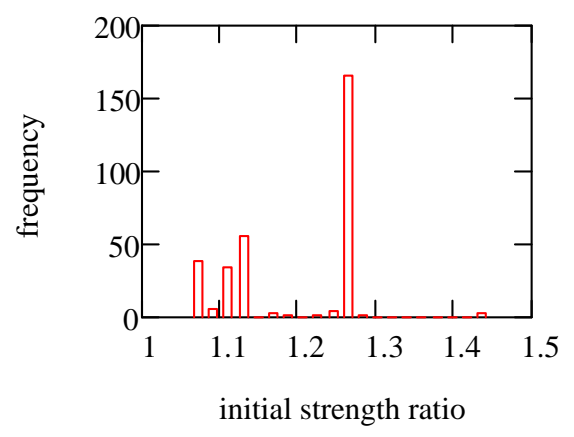

図-4 初期強度比の頻度分布

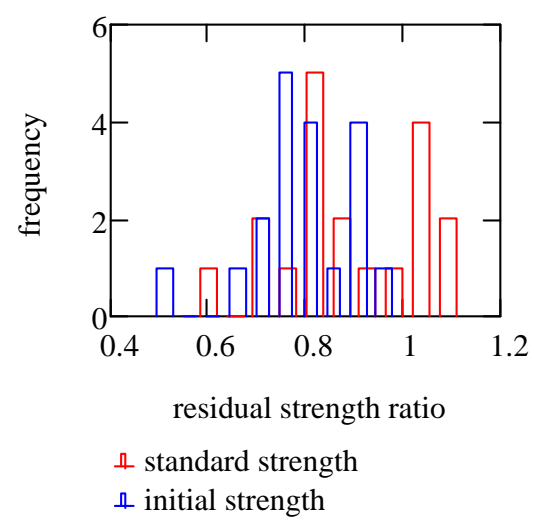

図-5 残留強度比の比較

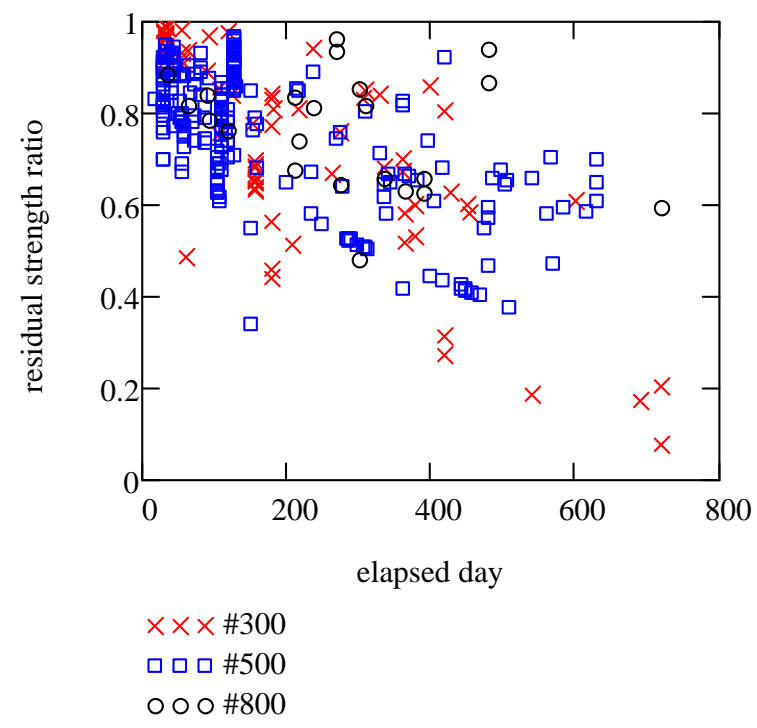

図-6 強度経時劣化関係 
図-5には50-60日経過時点の残留強度比を，規格值 (standard strength)に対する比で定義した場合と初期值(initial strengh) に対する比で定義した場合の比較を示した．標 準偏差は前者が0.145，後者が0.109であり，初期值に対 する比とすることで残留高度のばらつきをより正確に評 価できるといえる.

図一には全てのデータを対象に，経過日数に対する残 留強度比の関係を示した.データは大きくばらついてい るが，残留強度は0-100日程度経過の利用開始初期段階 で急激に低下し，その後徐々に緩やかに低下寸る傾向に あることが分かる。

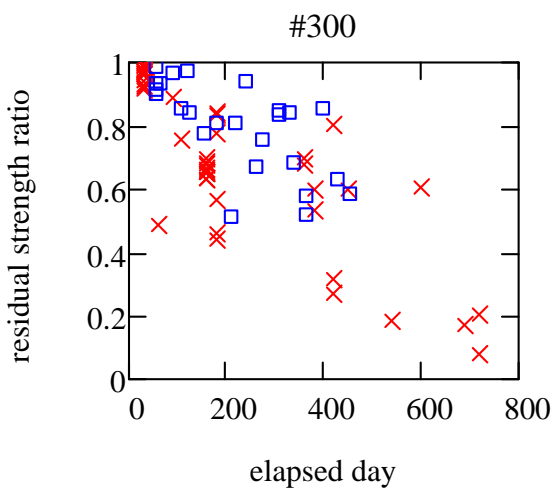

$x \times x$ virgin प्व reuse
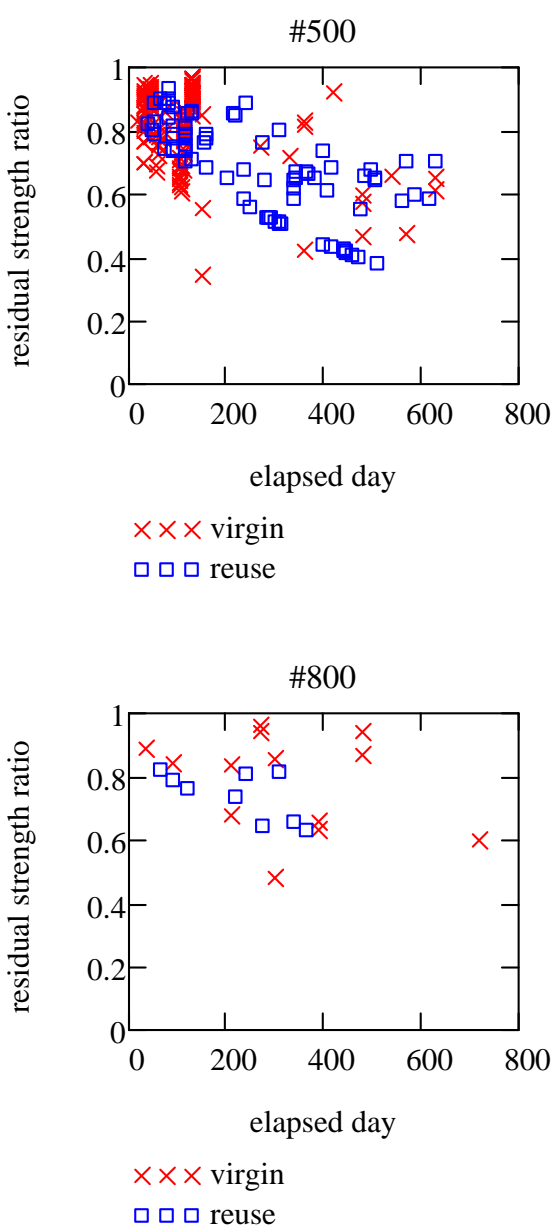

図-7 品番及び初期・再利用による強度経時劣化関係

\section{（3）品番及び利用状況の影響の検討}

品番の違いによる強度低下率の違いや，初期利用と再 利用の違いによる強度低下率の違いについて検討する.

図-7に品番ごとに経過日数に対する残留強度比の関係 を示した。困には初期利用(virgin), 再利用(reuse)の区別 も示した．再利用品については，初期利用終了時から1 回目の再利用までの保管日数は記録の残っている範囲で 21-256日の範囲で, 平均85日であった。上述のように品 番については\#500のデータ数が多く, 他の品番のデータ はあまり多くない，しかしながら，(2)の全データを対 象にした経過日数に対する残留強度比の項で述べた傾向 は概ね全ての品番に共通の傾向であるといえる. このた め, 品番の違いによる残留強度比の違いは考慮する必要 はないと考えられる.

次に利用状況による強度低下の違いであるが，図より 分かるように再利用のほうが初期利用よりも強度低下が 激しいような傾向は認められない. \#300のデータのよう に，初期利用の方が強度低下が大きい傾向も認められる. カーテンの再利用は資源の有効利用や廃棄物の発生抑制 等の観点から奨励されることであるが，再利用品の品質 確保のためには，污濁方止膜の解体・分別，運搬，清掃， 保管等を適切に行う必要がある1). 特に紫外線の照射に よる材料劣化が強度低下の主な原因と考えられることか ら，保管に関しては直射日光の影響を受けないように倉 庫で保管するなどの処置が施されており，このために再 利用品であっても初期利用と同等の強度率が期待できる ものと考えられる.

\section{（4）強度低下評価関数の検討}

以上の結果をもとに，全てのデータを対象として，強 度低下評価関数の検討を行う。

一般に，性能照査で用いる材料強度の值は，安全性の 余裕を考慮して平均值よりも低く設定される．実際の強 度設定方法に定まったルールがあるわけではなく, 各々 の分野で工学的判断に基づいて設定が行われている.た だし，ばらつきが大きい場合はより低く，ばらつきが少 ない場合は比較的高く設定することが合理的である。そ の意味で，平均值と標準偏差を用いて強度低下率を設定 することが合理的と考えられる.

2. で述べたように，性能照査では経時による影響以外 に，不確定要因によるばらつき $\left(k_{2}\right)$ や製品縫合による影 響( $\left.k_{3}\right)$ を別途考慮して強度を設定している．両者による 強度低下の割合は表-1に示したとおりであり， $k_{2} \cdot k_{3}=5.00$ の安全性の余裕が設定されている. この值は安全率に相 当する，従って，経時劣化の影響については，過度に余 裕を設定する必要は無いと考えられる.

ばらつきのあるデータからの強度設定法として，他分 野における材料強度の設定方法を検討すると，鉄筋コン 
クリート部材の終局曲げ而力，異形鉄筋降伏強度3)及び

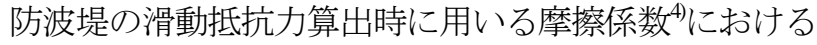

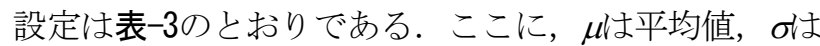
標準偏差である.

表より分かるように各分野の設定には幅があるが，本 研究ではカーテンの経時劣化特性として，上述の通り不 確定要因や製品縫合による影響が別途考慮されているこ とを考慮し，平均-標準偏差を強度の評価值の目標と考 えた.

表-3 強度関係パラメータの設定例

\begin{tabular}{|l|l|}
\hline 鉄筋コンクリート終局曲げ而力 & $\mu-0.8 \sigma$ \\
\hline 鉄筋降伏強度 & $\mu-2.5 \sigma$ \\
\hline 摩擦係数 & $\mu-0.4 \sigma$ \\
\hline
\end{tabular}
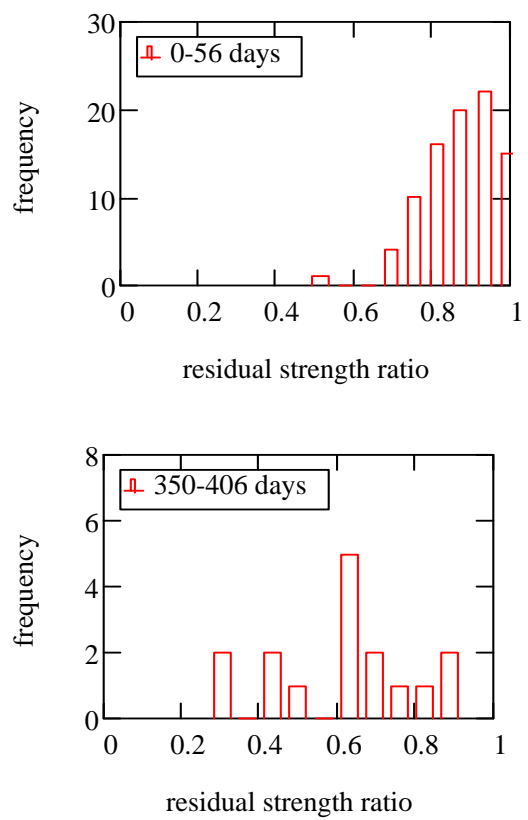

図-8 残留強度比頻度分布の例

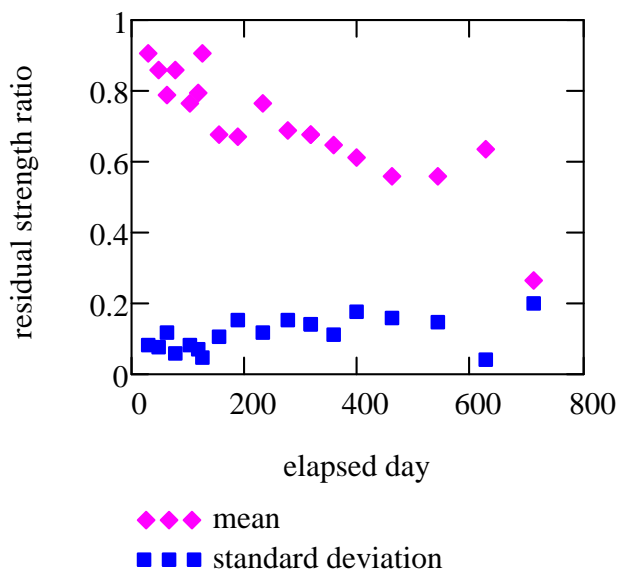

図-9 残留強度比の平均及び標淮偏差
図一より分かるように残留強度のデータは経過日数の 短いものが多いため，同じ重みで処理を行うと経過日数 の長いデータが反映されにくくなる．このため，10以上 のデータが含まれる2週間以上の範囲での経過日数の刻 みで平均值および標準偏差を算出した.

図-8に残留強度比頻度分布の例を，図-9に残留強度比 の平均及び標準偏差を示す。平均は経過日数に伴い減少 するが，標準偏差は120日程度までの範囲では0.10程度と 小さいが，それ以上の経過日数では0.15程度に増加する. なお図-8では経過日数の長い範囲の例として350-406日経 過の8週間のデータを示しているが，これは経過日数が 長い範囲ではデータ数がそしいためである，経過日数の 短い範囲についても同じ条件で比較するためにデータ数 は豊富であるものの0-56日経過の8週間のデータを示し ている.このため図-8の整理がそのまま図-9に反映され ているわけではないことに注意をしておく.

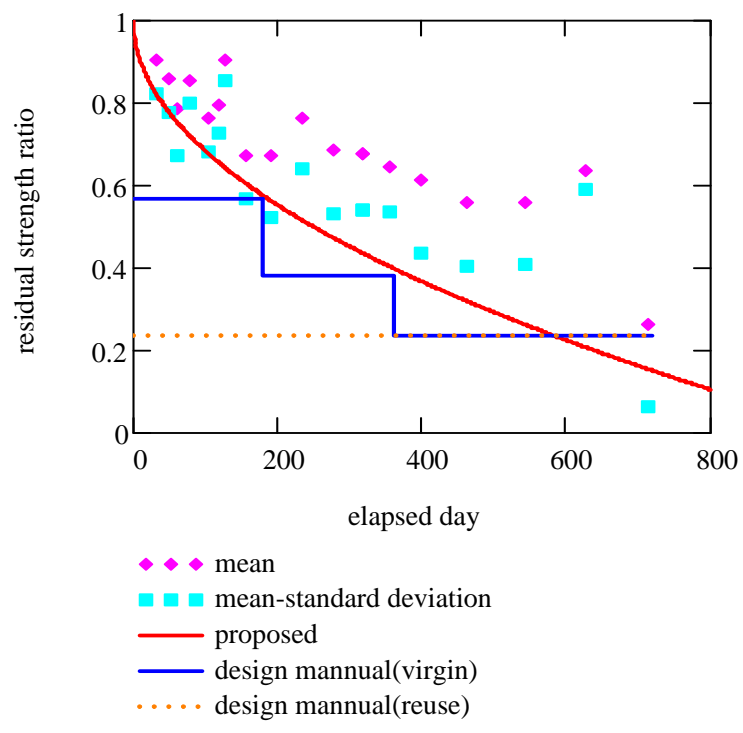

図-10 強度劣化関数

このように整理された平均-標準偏差の目標值に対す る評価式として，目標值の大半をカバーするものとして 様々な関数の適合性を検討した結果として，式(3)が得 られた。図-10に示す提案式は式(3)である.

$$
r=1-\sqrt{d / 1000}
$$

ここに, $r$ : 残留強度比, $d:$ 経過日数(日)である.

提案式と現行設計法1)を比較すると，経過日数が600日 程度以下の期間では，180日，360日程度では現行設計法 の初期利用の強度評価と提案式は概ね一致する. しかし ながら，それ以外の期間では提案式の方が高い強度を与 える，再利用品については，現行設計法では非常に安全 側に一定の強度で設定されているが，提案式では初期利 
用と再利用で同じ強度評価となるため, 通算の経過日数 が短い範囲では現行設計法よりも高い強度評価となる。

逆に経過日数が600日以上の極めて長い期間の場合は, 提案式の方が低い強度評価となる。

本研究では上述のように現行設計法策定時よりも多く のデータを収集するとともに，強度評価法も根拠のある 判断に基づいたものであるため, 現行設計法よりも合理 的な強度劣化の評価式が得られたと考えられる。

\section{4. まとめ}

本研究は，污濁防止膜カーテン強度を対象に，実工事 における製品回収時の試験データや実海域における実験 データ等の数多くの経時劣化データを収集し, 設計に用 いる劣化強度関数を提案した. 本研究による主な知見は 以下の通りである.

(1)污濁防止膜カーテンの残留強度は経過日数の増加に伴 って低下寸る. 本研究では強度の低下割合を示寸残留強 度比として, 残留強度と規格值の比ではなく, 残留強度 と初期值の比を用いた。 これは, 污濁方止膜カーテンメ 一カーの製品毎の初期值と規格值の関係にばらつきがあ るためである.

(2)設計では経時による影響以外に，不確定要因によるば らつきや製品縫合による影響などを別途考慮して強度を 設定している. ばらつきのあるデータからの設定法とし て，他分野における材料強度の設定方法を参考に平均標準偏差を強度の評価値の目標と考えた．10以上のデー
タが含まれる2週間以上の範囲で経過日数の刻んで平均 值および標準偏差を算出した. 平均は経過日数に伴い減 少するが，標準偏差は120日程度までの範囲では0.10程度 と小さいがそれ以上の経過日数では0.15程度に増加する. 目標值に対する評価式を提案した.

(3)品番の差による違いはほぼ無視できると考えられる. また，再利用による強度低下は，特に考慮する必要はな いと考えられる.

謝辞 : 本研究の取りまとめにあたり，污濁防止膜再利用 カーテン強度証明基準作成検討委員会 (委員長 : 新井洋

一 特定非営利活動法人リサイクルソリューション理事

長）の委員の方々より貴重な意見を頂きました. ここに 記して感謝します。

\section{参考文献}

1）港湾空港建設技術サービスセンター：污濁防止膜技 術資料（案）， 2008.

2) 島田 伊浩, 新井 洋一, 長尾 毅, 三吉 正英, 山本 直 文, 岡本 直, 石坂 修, 須藤 彰二 : 污濁防止膜の経過 月数による強度劣化に関する実海域実験, 土木学会 論文集 B3（海洋開発）, Vol. 69(2013), No. 2，投稿中.

3) 長尾 毅：ケーソン式防波堤の終局曲げ安全性照査 に関寸る信頼性設計手法の提案, 土木学会論文集 No.696, I -58, pp.173-184, 2002.

4) 長尾 毅：ケーソン式防波堤の外的安定に関する信 頼性設計法の適用，土木学会論文集 No.689， I -57, pp.173-182, 2001.

\section{A STUDY ON EVALUATION METHOD OF STRENGTH DETERIORATION FOR SILT CURTAIN}

\section{Takashi NAGAO, Yoshihiro SHIMADA , Masahide MIYOSHI, Yasuyuki KOSAKA, Masahiro RIKITAKE and Hiroyuki AZUMA}

This study aims at proposing the new evaluation method of strength deterioration for silt curtain. As strength deterioration is inevitable for silt curtain and there exist many uncertain factors regarding strength of silt curtain, present design method evaluates stregth deterioration on the very conservative side especially for reuse curtain.

Authors collected 315 datum on strength deterioration for silt curtain from experiments after construction works and field experiment results. Authors proposed an equation for the evaluation of strength deterioration for silt curtain based on the statistical data analysis. 